\title{
Cultural Diversity, Ethnocentrism and Terrorism in Mukoma WA Ngugi's Black Star Nairobi (2013)
}

\section{Babacar Diakhaté}

Laboratoire d'Études africaines et postcoloniales, Université Cheikh Anta Diop Dakar, Sénégal E-mail: diakhatebabacar83@hotmail.fr

\begin{abstract}
:
This article brings to light the obstacles that impede countries like Kenya to develop. In Black Star Nairobi, Mukoma WA Ngugi addresses cultural diversity issues and ethnic crisis. Like other African writers such as Chinua Achebe, Ngugi WA Thiong'o, Chimamanda Ngozi Adichie, Mukoma WA Ngugi displays to what extent Kenyans are tied to their cultures, traditions and ethnics. He demonstrates how ethnocentrism can have an impact on the sociopolitical activities of his people. He also pinpoints the drawbacks engendered by ethnocentrism like radicalization, terrorism and illegal immigration.
\end{abstract}

Keywords:

culture; ethnocentrism; terrorism; radicalization; immigration

\section{Introduction}

Kenya became independent in 1963 from the British colonial administration. However, since the departure of the British colonizers, Kenya is frequently confronted with social class issues, ethnic crisis, political instability; etc. Mukoma WA Ngugi releases Black Star Nairobi (2013) in which he draws his readership's attention on the above-mentioned evils. This article highlights to what extent Kenyans are linked to social classes and ethnics. This ethnocentrism causes political instabilities and terrorist affiliations in the country. It displays that social classes and ethnic crisis influence marriages and elections. The first section brings to light the weight and the importance of culture and ethnic in Kenya. The second part displays ethnic paranoia between Kikuyus and Luos. The last part shows the radicalization of people towards their political classes.

\section{Review of Literature}

\subsection{Cultural Diversities and Ethnic Crisis}

"Culture" refers to customs, practices, languages, values that define social groups such as those based on nationality, ethnicity, religion... Moreover, culture can also be defined as the sum total of the answers people give to the questions of life. Dickson Kanakulya defines culture:

Culture entails elements of thought, speech, and action. These embody behavioural and learning patterns and transmission of those patterns to successive generations by way of language (verbal and non-verbal) and communication. Culture is synonymous with community and it influences our ideas and living very much more than we realize (Kanakulya, 2003:58).

A strong cultural identity expression can hinder other groups from asserting themselves. Members belonging to such small groups can feel alienated from their society. Andrew Smith argues that the focus on hybridity suggests that the two entities being mixed were somehow "pure" beforehand (Andrew, 2008: 257). Bonny Castle in turn echoes that 
post-colonial leaders create living culture which responds to the current reality facing the native population (Castle, 2002: 210). In Black Star Nairobi, Mukoma WA Ngugi castigates how ethnic crisis motivates some different communities to be paranoiac towards others.

\section{a. Inter-Ethnic Marriage}

Cultural diversities and Ethnicity impede Africa to be a very peaceful place where people can live in harmony. In Black Star Nairobi, WA Ngugi uses two characters from different tribes to illustrate it. $O$ is Mary's husband and they are respectively from Luo ethnic group and Kikuyu. During their marriage, they do not use their ethnic languages to communicate but they speak English. Their main problem is when Mary dies in the Norfolk bombing in Nairobi and O's parents refuse to bury her in their village. Wa Ngugi asserts that Mary was a Kikuyu and O, a Luo living in Nairobi, isolated from their fellow ethnic group O's family did not want to burry a Kikuyu woman (Wa Ngugi, 2013: 102).

$\mathrm{O}$ and his family's relationship ails when they discover that Mary is a Kikuyu. $\mathrm{O}$ is between the devil and the deep sea. The devil of his family who does not want his wife to be buried in his village, and the deep sea of a husband who wants to accompany his deceased wife up to her last resting place. O puts: In my mother's world, one's ethnicity matters more than life and death itself. She is my wife. I am his son. She is her daughter (Wa Ngugi, 2013: 103).

In Africa when a man gets a wife, the latter is supposed to take care of the whole family. It is not wife and husband marriage only, but father and mother in-laws, brothers and sisters-laws, uncles and aunts are included. If the wife does not play fully her social duty, her marriage can fail. $\mathrm{O}$ asserts I live with myself after costing Mary her life... This was no longer about a man and his wife, but about what our family want (Wa Ngugi, 2013: 103).

In Half of a Yellow Sun, Chimamanda Ngozi Adichie pinpoints cultural diversities and ethnic crisis through Master and Olanna's marriage. Master's mother never accepts her son to get married with a woman of another ethnic group. Olanna and Master are from distinct ethnic groups. Olanna has also been abroad to deepen her studies and she comes back home with her qualifications. Many African rural women do not want their sons to get married with highly qualified women.

In Black Star Nairobi, the presence of Jane and Muddy as refugees in Kenya is a reminder of the ethnic crisis in Rwanda. The former is $\mathrm{O}$ and Mary's adoptive daughter, and the latter is Mary's best friend. Wa Ngugi takes the example of the "Rwandan 1994's genocide" to warn his people about the danger of ethnic crisis. It was between the Hutu and The Tutsi. This ethnic civil war lasted at least three months and caused around one Million deaths. In Black Star Nairobi, this phenomenon is experienced between the Kikuyus and the "Traitors". The Traitors were Kenyan people who oppressed, killed their fellow citizens in favor of British people in Kisuma, the headquarters of the Luos:

In Kisuma, Kikuyu were being pulled out of their homes and cars and killed. The police had killed enormous protestors from the opposition. Some of the opposition leader had gone back to their constituents to organize them into militia...the police deployed in the rural areas had broken along ethnic lines, and had gone on along killing rampage (Wa Ngugi, 2013: 123). 
This engenders reprisals among the traitors by the Kikuyus who killed them. Wa Ngugi puts Kikuyu treated their traitors -traitors were cut into little pieces (WA Ngugi, 2013:135).

Differently from in Black Star Nairobi, in Things Fall Apart Chinua Achebe gives another way out to settle ethnic crisis. Achebe presents Umuofia and Mbaino communities. In the morning, a speaker of the Umuofia community informs that a man of the Mbaino community kills a woman of Umuofia village on her way to the market. While everyone in Umuofia village expects to respond violently, the grownups settle the problem out of court by proposing two choices to the Mbaino village. Either the Mbaino village sends a man who works for the king and a virgin young girl as compensation or a war is declared. Umuofia people are very dreadful and courageous in war because of their sense of "togetherness". Umuofia is the most powerful village in the area thanks to its fierce fighters included Okwonkwo and strong practitioners of magic.

Chinua Achebe's method to solve the tension and avoid war is just a response to African detractors who think that Africans do not know neither democracy nor social justice. The fact of calling the members of the community to consult their opinions is enough to illustrate African traditional form of democracy. The compensation is a symbol of social justice.

Mukoma WA Ngugi and Chinua Achebe show two different approaches to settle ethnic crisis. While Achebe chooses social justice, Wa Ngugi resorts to violence, or even death. In Black Star Nairobi, O thinks that if he announces his wife's death, this will alleviate the tension and hatred. But no such a thing happens. O puts in my mother's world, one's ethnicity matters more than life and death itself (Wa Ngugi, 2013:103). Indeed, the sympathy that $\mathrm{O}$ and Mary's ethnic groups expect from O's mother is vain. His mother is conservative and very deep-rooted in her culture and tradition.

O's mother is different from Mary who is characterized as an iconoclastic person who "deconstructs" what has been left to her by her ancestors. Mary affirms "Men ear trousers and women don't" Mary goes back in the house and wears a trousers saying "I am a man now" (Wa Ngugi, 2013:138). Ngathia, Mary's father is a victim of his daughter's anti-conformism. He is killed later by his ethnic group for marrying his daughter to a Luo. According to kikuyus, marrying one's daughter to a Luo is a "traitor" practice, so Ngathia has to be treated as a traitor. They kill him because his daughter married a Luo. But that makes him murderers worse- they are traitors to human race (WA Ngugi, 2013: 135).

\section{b. Ethnicity and Politics}

Beyond marriages and other social activities, ethnic crisis is also manifested in the political sphere. Civil wars have been brought about by ethnic issues and this has even some impacts in politics. In general, most political militants or citizens no longer care about the agenda presented by their candidates. Social, economic and cultural policies for development are not debatable issues in politics. It is who the candidate is and to which ethnic group he belongs. Ethnicity takes over from political agenda. In Black Star Nairobi, Wa Ngugi draws his readers' attention on this threat for African stability. The Norfolk bombing in Nairobi is caused by another ethnic group who wants to impeach the ruling political class legally elected. This ethnocentrism is what Wa Ngugi depicts in Black Star Nairobi. As he puts:

Yet I could not but think that we were at war with people who just a few days ago had been civilians. Here, in is Kisumu, in Nairobi, and in the Rift Valley, Luos 
Kalenjins, and Kekuyus were killing each other in the name of the fat motherfuckers who were now discussing the future of the country in the comfort of the KICC ( WA Ngugi, 2013: 136).

In Black Star Nairobi, Half of a Yellow Sun, A Kind of Marriage and Things Fall Apart respectively by Mukoma WA Ngugi, Chimamanda Ngozi Adichie, Buchi Emecheta and Chinua Achebe all these emblematic figures from different generations of African literature are very concerned about ethnic issues. According to them, Africans should eradicate and take up the challenge of the evils that stifle Africa. He puts People die from hunger because of bad politics, malaria has not been eradicated because of bad government, and then there is war (Wa Ngugi, 2013: 231).

\section{Discussion}

\subsection{Legal Immigration}

In many African literary fictions the incentive factors that push a person to travel to other destinations are distinct and numerous. In Chika Unigwe's Black Sisters Street, Sisi and all her friends go to Belgium because of lack of job opportunities after getting their diplomas. In this same vein, in We Need New Names, No Violet Bulawayo, presents his very young characters who try to eke out a living in the streets of Zimbabwe. They are disappointed when the programme of "restoring order" demolishes all their houses and places of work. The irony of "Paradise" as "Kaka" illustrates Bulawayo's characters' disillusion, which leads them to go to America.

As opposed to Unigwe and Bulawayo, Mukoma WA Ngugi displays his characters' incentive factors another way round. In Black Star Nairobi, O, Ishmael and Muddy travel to Mexico and San Francisco. Their displacement is not motivated by money. They go to Mexico to do investigations about the people who are involved in Norfolk Nairobi Bombing that kills Mary. They want to avenge Mary's death. What Unigwe, Bulawayo and Mukoma WA Ngugi have in common is they talk about illegal immigration. All their characters change their names of origins. Admittedly, (re)naming is an important element in the candidates for illegal immigration process. Indeed, Ishmael becomes James Mwangi, $\mathrm{O}$ is called Patrick Onyango and Muddy is known as Jane Mwangi, Mrs Mwangi as James Mwangi's husband. Ishmael confirms:

My name was no longer Ishmael Fofona- It was James Mwangi. I learned over and looked at O's. His name was Patrick Onyango. "Look, Muddy, they will need you... a beautiful woman creates an aura of good will". Muddy laughed when she saw her name. "James Mwangi, your trophy illegal immigrant wife (Wa Ngugi, 2013: 143).

The phenomenon of the flourishing business in the transportation of the candidates for emigration must be addressed. Like in Chika Unigwe's On Black Sisters Street, in Wa Ngugi's Black Star Nairobi, O, Muddy and Ishmael are taken in charge by Julio who transports human beings to Mexico. Julio's proposal to take them from Mexico to America is the only way out to achieve their aim. These candidates for illegal immigration flee the civil war (violence) in Kenya to land in Mexico to face another violent area to avenge Mary's death. They cross Mexican borders and create conflicting tensions with border checkers. Wa Ngugi puts ...why had we fought back? Why didn't we walk away? Why was he dying, Why were we in Mexico? Why had I betrayed our country (Wa Ngugi, 2013:179)? Julio takes many advantages of the human transportation to America. 
Black Star Nairobi, The New Tribe, We Need New Names, On Black Sisters Street and Fragments are all fictions that address immigration. However, their authors tackle the issue in different approaches. The final results of their immigrants are not the same. Indeed, in On Black Sisters Street and We Need New Names, their characters lose their cultural identity and values. Their lives have negatively changed. In parallel, in The New Tribe, Chester leaves from England for Nigeria to find his origins. In, Ayi Kwei Armah's Fragments Baako goes to Germany to further his studies and comes back with a guitar.

Contrary to the aforementioned fictions, in Black Star Nairobi, Wa Ngugi shows how his characters such as $\mathrm{O}$, Muddy and Ishmael lose interest in looking for money in America. Their objective is achieved for capturing Sahara and Mr Delaware to avenge Mary's death. They discover that Mr Delaware is responsible for Mary's death through Sahara. He puts "Where is Delaware? Tell me where he is and we will call you an ambulance" "He was so determined to get Sahara and avenge Mary's death that was willing to make concessions that just a few weeks ago he would have made" (Wa Ngugi, 2013: 217).

\subsection{Supposed-Terrorist Affiliations}

Social and economic injustice can have some repercussions in the lives of the poor people who are victims of bad repartitions of resources. When an elite class shares among themselves the economic advantages of a country at the detriment of the masses, this can lead to rebellion. Moreover, a bad political leadership can trigger off juvenile delinquency, illegal immigration, radicalization; etc. In Black Star Nairobi, Wa Ngugi depicts a bad political system that prevails in Kenya. He castigates Kenyan political leaders who do not improve the hard living social and economic conditions of their citizens.

Poverty gives rise to many movements of radicalization. In Black Star Nairobi, the author presents Ishmael, a disgruntled black American Muslim who has become radicalized in Kenya. Norfolk, one of the most prestigious and luxurious hotels in Nairobi and frequented by the political class becomes the target of the terrorists. As Mukoma WA Ngugi Puts:

Years ago, Amo Apara had come to him with some disturbing news. IDESC was planning to set off bombs in Kenya. The purpose: to destabilize the government by targeting leaders from all the political parties. In the absence of the leadership class, IDESC would take over stewardship of the country and cultivate a new leadership recruited from the youth who respected democracy- a second independence (Wa Ngugi, 2013: 247).

While in Black Sisters Street and We Need New Names Sisi, Alice and Alex resort to illegal immigration, in Black Star Nairobi, O, Ismael and Muddy all manifest their frustration by radicalizing themselves. They become terrorists to impeach the contemporary political system. Terrorism is the unlawful use of force or violence against persons or property to intimidate or coerce a government or its citizens to further certain political or social objectives (...) (Austintexas. Gov).

Muddy was a Rwandan ex-guerilla fighter who had fallen under sway (Wa Ngugi, 2013:75). She refugees in Kenya and becomes Mary's best friend. All these characters are presented in Black Star Nairobi as people who need a wind of political change in their countries.

In Black Star Nairobi, the radicalized Kenyans such as Sarah, O, Ishmael and $\mathrm{Mr}$ Delaware are manipulated by powerful foreign associations and people. Sarah is accused of placing the bomb in Norfolk for being connected to famous and powerful foreign leaders. Sahara's connection with Thatcher's office manager, Reagan's personal assistant, Clinton's one 
time legal advisor, Koffi Annan's special advisor and an assistant managing director of the Mandela Foundation, makes him suspicious. Wa Ngugi illustrates:

... So we have these guys all connected to powerful people or formerly powerful people, meeting with Sahara. We know Sahara planted the bomb in Norfolk. We know he scouted other locations in Kenya, but we didn't find anything. Yet he wanted to stop our investigations (Wa Ngugi, 2013: 214)

Even though some African political leadership leaves to be desired, the interference of Western leadership is depicted by pan-African activists. They also accuse a bad African political class leadership whose aim is a social mobility. Sefi Atta calls them the nouveau riche. She puts they steal money from the government, from a bank, from somewhere, a generation later; they are looking down on others (Atta, 2010:23).

Atta brings to light the reasons for Ben Laden, affiliated to Al Qaeda, to destroy the Twin Towers of the United States on September 11, 2001. According to her, Ben Laden destroys The Twin Towers because they are a symbol of American Economic Imperialism (Atta, 2010:270). Even though the twin towers symbolize American Economic Imperialism, Atta describes the way in which the radicalized Muslims destroy buildings and kill innocent people.

Terrorists kill many other innocent people. Mary has nothing to do with the political class but she is one of the victims of the Norfolk terrorist attack. Wa Ngugi affirms the terrorist is an enemy without a face, a name and a history; there is no way of knowing where they will attack us (Wa Ngugi, 2013: 43).The interfering of Western powers to impeach, through some lobbies, the contemporary African political leaders cause many disasters to the low populations. Wa Ngugi asserts when two elephants fight, it's the grass that suffers (Wa Ngugi, 2013: 27).

\section{Conclusion}

Like Chimamanda Ngozi Adichie and Chinua Achebe respectively in Half of a Yellow Sun and Things Fall Apart, Wa Ngugi's Black Star Nairobi deals with cultural diversities and ethnic issues. Wa Ngugi exposes how Kenyans are linked to their cultural tradition and ethnic. Indeed, O's mother disapproves of her son's marriage with an extra-ethnic girl. After Mary's death $\mathrm{O}$ puts in my mother's world, one's ethnicity matters more than life and death itself (Wa Ngugi, 2013:103). Wa Ngugi shows how this ethnic crisis influences the political class. For him, it is not a political agenda but ethnic issues. This ethnic crisis leads some Kenyans to radicalization and get involved in supposed-terrorist affiliations. Norfolk hotel bomb in which Mary dies is a symbol of the existence of terrorist movements in Nairobi.

\section{References}

Achebe, Chinua (1958). Things Fall Apart, London: Heinemann.

Adichie, Chimamanda Ngozi (2003). Purple Hibiscus. London: Harper Perennial.

- (2009a). Half of a Yellow Sun. London: Fourth Estate.

Armah, Ayi Kwei( 1974) Fragments, London: Heinemann.

Atta, Sefi (2010). News From Home, Interlink Book.

Bulawayo, No Violet (2013). We Need New Names. New York: Hachette Book Group.

Castle, Bonny, Stephen, In Search Of Authority: "An Introduction Guide To Literary Theory”,

Second Edition Broad New Press, Peter Borough, 2002, .P.210.

Emecheta, Buchi (1986). A Kind Of Marriage. Macmillan Publisher.

..., The New Tribe (2000) African Writers Series, London: Heinemann. 
Kanakulya, Dickson T (2003).Is Of the Department of Philosophy, Makerere University, Kampala, Uganda. He Is Also The Assistant Coordinator Of Undergraduate Programmes. He Published "Towards A Richer Intercultural Philosopby For Africa", Appeared In International Journal Of Humanistic Studies, Vol.2, P. 58.

Smith, Andrew,( 2008). "Migration, Hybridity and Post-Colonial Literary Studies", in Lazarus, Neil (ed). The Cambridge companions: Post-Colonial Literary Studies, Cambridge University Press, Cambridge, p.257.

Unigwe, Chika (2009) Black Sisters Street. Random House: New York.

Wa Ngugi, Mukoma, Black Star Nairobi, ((2013).Melville House. 